\title{
Cavity-nest boxes for solitary bees: a century of design and research
}

\author{
J. Scott MacIvor \\ Department of Biological Sciences, University of Toronto Scarborough, 1265 Military Trail, Toronto, ON M1C 1A5, \\ Canada
}

Received 25 May 2016 - Revised 3 September 2016 - Accepted 26 September 2016

\begin{abstract}
A variety of solitary bee species that naturally nest in wood and plant stems aboveground also readily accept nest boxes, which are human-made devices that aggregate these nesting conditions. Nest boxes are sheltered bundles of hollow plant stems, bamboo or reeds, and holes drilled into wood or cavities made of other materials such as glass or polystyrene. In this paper, I examine the best practises in nest box material selection and construction, and the use of nest boxes to address four basic objectives related to our understanding of bee biology and enhancement of pollination services. A variety of materials and cavity dimensions are included in nest boxes that are used to monitor local bee diversity or to address fundamental questions in community ecology and environmental change. Others examine bee biology, physiology and behaviour that use nest boxes to obtain bees for further experimentation. The majority of studies use nest boxes in agricultural landscapes and in alternative pollinator management; these studies improve nest box design for target bee species to augment their numbers. Continued design and data sharing, as well as the refinement of nest box construction and deployment for specific objectives, will ensure they remain useful tools for bee science, conservation and alternative pollinator management.
\end{abstract}

cavity-nesting bees/alternative pollinator management/wild bees/biodiversity/agroecosystems/trap nest/bee hotel / pollinator garden

\section{INTRODUCTION}

Different survey methods and sampling tools are available to study wild bees in their natural habitats. Some of these techniques sample broadly, such as pan traps (Kearns and Inouye 1993; Gezon et al. 2015), window traps (Rubene et al. 2015), Malaise traps (Malaise 1937; Darling and Packer 1988), sweep netting (Richards et al. 2011) and observations of visitors to flowers (Deguines et al. 2016). Other survey methods target certain taxa by creating analogues of their nesting habitat. A few examples include Fussell and Corbet (1992) making wood and clay-brick

Corresponding author: J. MacIvor, scott.macivor@utoronto.ca

Manuscript editor: Alexandra Klein nest sites for bumble bees $(1.5 \%$ colonized of $N=654$ nests set out over 3 years), Sheffield et al. (2014) setting out overturned flower pot saucers ('nesting saucers') for Osmia inermis (Zetterstedt) which nest at the surface of the ground under stones $(10 \%$ colonized of $N=60$ ), and Silva et al. (2014) using plastic bottles treated with propolis and wax to attract nesting colonies of stingless bees (five species, $3.5 \%$ colonized of $N=720$ over 2 years).

Another method having far greater success in attracting a target community of bees are nest boxes (also 'trap nests', 'bee condos', 'bee hotels', 'bee boxes') (Maeta and Kitamura 1964; Krombein 1967; Bosch and Kemp 2002; Tylianakis et al. 2005; Westphal et al. 2008; Holzschuh et al. 2009; Barthélémy 2012; MacIvor et al. 2014). These bee species are solitary and in each nesting cavity, a reproductive female will construct brood cells in a linear series 
from the back of the tunnel to the front. Depending on the species, she will partition each brood cell using materials that are taxon-specific and can include cut pieces of leaves, tree resins, mud or pebbles (Krombein 1967; Cane et al. 2007). As a group, these bees are referred to as cavity nesters and naturally nest in hollow plant stems, cavities in wood or other structures above ground, including those in human-made infrastructure such as nail holes (Raw 1972) and cracks in mortar between bricks (Blochtein and Wittmann 1988). As central place foragers, once a suitable nesting site is found, bees will forage within a range around this site, provisioning the nest with the various resources they seek (Gathmann et al. 1994; Peterson and Roitberg 2006). As a result, identifying the nesting location of a bee provides information on its resource use and the environment in which it is living, not just where it is passing through (Grixti and Packer 2006).

Nest boxes have been used to observe and study cavity-nesting bees for more than a century and initially were largely inspired by observations of bees constructing nests in naturally occurring materials. In 1918, the naturalist and writer Jean-Henri Fabre described the nest building activities and homing abilities of mason bees nesting in the straw thatching that formed his roof (Fabre 1918). BalfourBrowne's (1925) 'bee wall' used bricks to hold elderberry stems and glass tubes in place to survey local cavity-nesting bees in his residential garden. Over time, different materials were tested for field durability, ease of maintenance and use by different species, including glass tubes (Hartman et al. 1944), plant stems (Rau 1937; Hicks 1937; Frost 1943) and holes drilled in wooden blocks (Peck and Bolton 1946; Bohart 1955). These early investigations and field observations led to the use of nest boxes in agriculture as a means of augmenting solitary bee pollinators of flowering crops (Bohart 1955; Medler 1958; Fye 1965a; Raw 1972; Maeta and Kitamura 1974; Torchio 1976).

Nest boxes today are made from a wide range of materials with no two designs the same. Many are small and sold in stores to gardeners, readymade or as DIY projects. Those used in agriculture are usually much larger than those in home gardens or public spaces (Wilson et al. 1999). In all cases, basic features of a nest box include a sheltered set of a few to several hundred nesting cavities made of porous materials such as wood, cardboard or polystyrene, opened at one end only, and (optimally) about $15-20 \mathrm{~cm}$ in length and an internal diameter of $<1 \mathrm{~cm}$.

Studies that use nest boxes can be grouped in two ways: (1) those intending to study bees in a natural setting and (2) those augmenting numbers to obtain bees for pollination services or for experimental research. In the first example, using nest boxes to study bees has led to a significant understanding of key aspects of their ecology, diversity, nesting, and foraging biology, as well as how environmental factors impact their populations. Using nest boxes to study how bees respond to landscape changes, such as those resulting from urbanization (MacIvor and Packer 2015; Fortel et al. 2016) or climate change (Forrest and Thomson 2011) could be extrapolated to impacts experienced by all bees (Westphal et al. 2008). In these studies, nest boxes are a key component of the experimental design; for example, researchers consider its design, how many and where they are placed to best answer a set of questions. In the second example, nest boxes are simply tools used to increase the number of bees for pollination services or for further experimentation ancillary to the nest box used to obtain the bee specimens. In each example, nest boxes play an important role but require different designs, materials and implementation.

In this paper, I identify best practises for material selection and construction of nest boxes for cavity-nesting bees and recommend design criteria to address four primary objectives. Two of these objectives require nest boxes to monitor bees in their environment and two utilize nest boxes to enhance numbers of bees for management or further experimentation. A secondary goal in surveying the literature on this topic is to highlight to readers the broad applications of nest boxes as tools in the study of bees and in bee education, to enhance target species for pollination and engage local communities with wild (e.g. non-honey bee) pollinators. 


\section{DESIGN CONSIDERATIONS}

A variety of materials are used to construct nest boxes to house cavity-nesting bees (see https:// resonatingbodies.wordpress.com). Many factors impact the effectiveness of nest boxes including the material and dimensions (length, width) of the nesting cavities, as well as pattern and colour of the nest box, and its positioning, orientation and the timing of placement in the habitat studied (Krombein 1967; Bohart 1972; Budrienè et al. 2004; Gaston et al. 2005; Everaars et al. 2011). As a result, there is no general consensus on the 'best' nest box and researchers tend to use their own designs based on regionally available materials (Dicks et al. 2010). In general, the materials used to make nest box cavities can be delineated into four main types: (1) holes drilled in wood; (2) bamboo, reeds and hollow plant stems; (3) cylindrically rolled paper or cardboard tubes and (4) artificial materials such as glass, polystyrene or other plastic (Table I).

\subsection{Nesting materials}

Wooden nest boxes, especially those set out over multiple seasons (Fairey and Lieverse 1986), are generally more attractive to bees than any other materials (Figure 1), including vermiculite boards (Martins et al. 2012) and polystyrene (Torchio 1984), but rarely are the type or species of wood used identified in studies. Pine (Pinus : Pinaceae) is most commonly identified and other wood types used include fir (Abies: Pinaceae) (Coville and Griswold 1984), aspen (Populus: Salicaceae) (Peck and Bolton 1946), cedar (Thuja: Pinaceae) (Jennings and Parker 1987), oak (Quercus lobata Née: Fagaceae) (Barthell et al. 1998), and redwood (e.g. Torchio 1981).

Another common method for constructing nest boxes is to bundle together hollow stems, or stems having soft pith which is excavated by certain bee species (Figure 1). These stems range considerably in internal diameter (2 to $20 \mathrm{~mm}$ as in Gathmann et al. 1994; Tscharntke et al. 1998; Matsumoto and Makino 2011). 'Bamboo' is used generically to describe nesting cavities in numerous papers without a clear indication of which species was used (Figure 1a). 'Reed' is also used often to describe the source of nesting cavities, and the dominant reed identified to species is Phragmites australis (Cav.) Trin. ex Steud. (Family: Poaceae), with one other reed species used Saccharum spontaneum L. (Poaceae) (Kessler et al. 2009). Three globally invasive plant species, Phyllostachys aurea C.R. Riviere (Poacaeae) (Musicante and Salvo 2010), Arundo donax L. (Poaceae) and Fallopia japonica (Houtt.) Ronse Decr. (Polygonaceae) are also used and collecting them for nest boxes could contribute to management and outreach (Table II). Among hollow and pithy stems and branches, the most commonly used are elderberry (Sambucus: Adoxaceae) (Hicks 1937; Cane et al. 2007), raspberry and blackberry (Rubus : Rosaceae) (e.g. Hicks 1937; Danks 1971) (Table II).

Extruded polystyrene nesting boards can support large populations of solitary bees and have been developed for managing them for pollination services in agricultural systems (Rothschild 1979; Kemp and Bosch 2001; Radmacher and Strohm 2010, 2011) (Figure 1). Richards (1978) found polystyrene supported higher numbers of viable offspring than other nest box materials including paper and cardboard tubes. Brood cells in boards can be mechanical harvested and easily cleaned and this innovation has made the production of Megachile rotundata (Fabricius) a profitable industry and a model system for other cavitynesting bee species managed as alternative pollinators.

\subsection{Nesting cavity dimension}

Nesting cavity length and diameter vary widely between studies, and choosing the correct dimensions can improve colonization by the species of interest (Fye 1965a; Krombein 1967). Among studies that report nesting cavity diameters, these range from as low as $2-3 \mathrm{~mm}$ to as high as $25 \mathrm{~mm}$ (e.g. Kessler et al. 2009). Bees select cavities that match their own body width to ensure the brood cells fit tightly and reduce pathways for parasites to access brood deeper in the nest. For example, studies interested in small cellophane bees (Hylaeus spp.) should use diameters between 1 and $4 \mathrm{~mm}$, whereas diameters between 5 and $8 \mathrm{~mm}$ should be used for medium-sized bees 


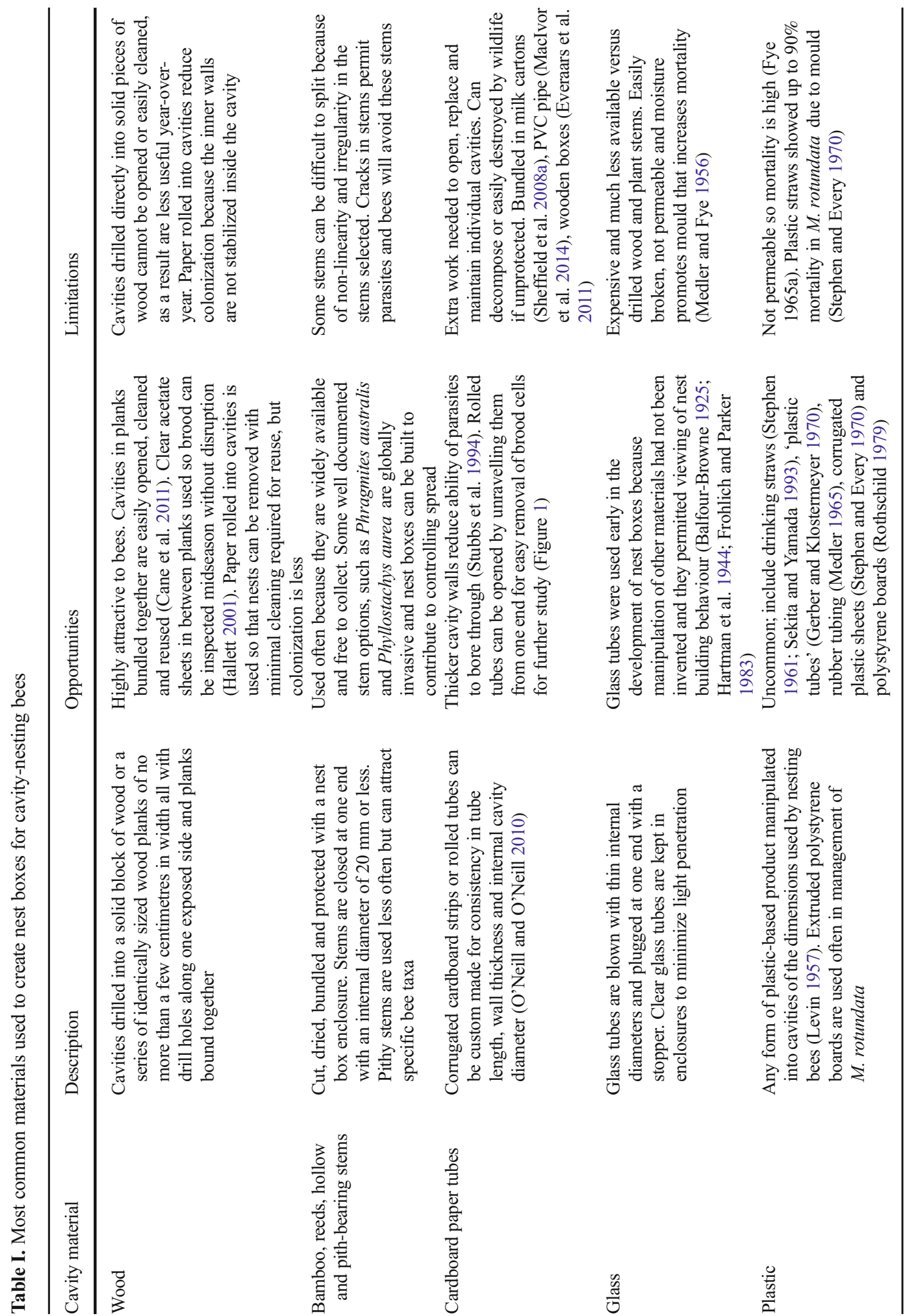




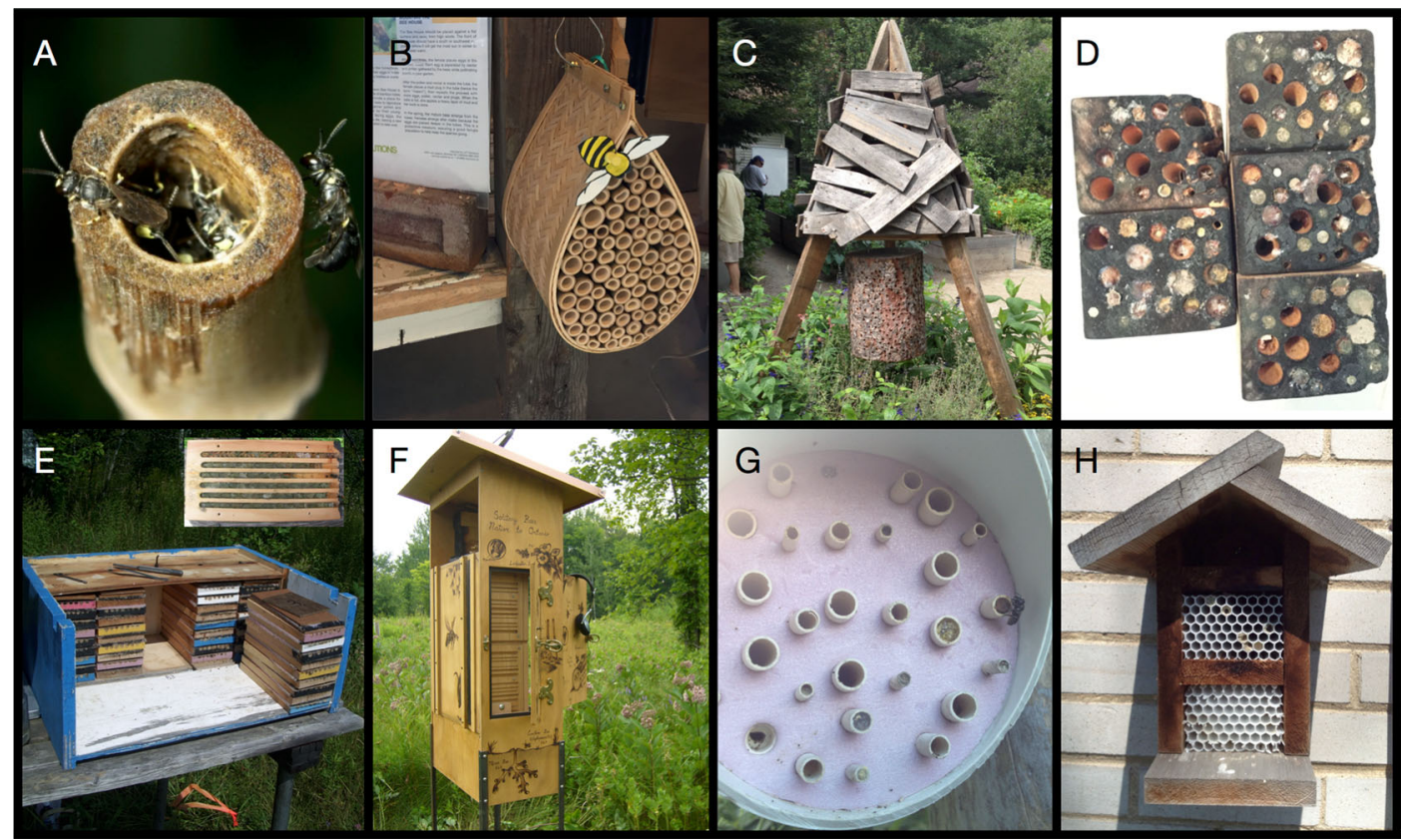

Figure 1. Different nest boxes and materials used to construct them. a, b Bamboo reeds (a photo credit: Stephen Humphreys). c, d Drilled holes in wood blocks. e, f Wood cartridges. g Cardboard paper tubes. $\mathbf{h}$ Extruded plastic tubes.

(e.g. Megachile or Osmia spp.). Nesting cavity diameter can influence bee sex ratios, such that less-desirable nest sizes result in a reduction in female offspring (Stephen and Osgood 1965). Studies investigating the consequences of an altered sex ratio on population dynamics and resulting pollination levels use nest cavities of varying diameters so that these comparisons can be made (Krombein 1967; Rothschild 1979; Longair 1981).

In general, nesting cavity lengths should be approximately $150 \mathrm{~mm}$, but some range up to 200-300 mm, and others much shorter. For example, $50 \mathrm{~mm}$ in Paini (2004), 58-85 mm in Gazola and Garófalo (2003), $70 \mathrm{~mm}$ in Zillikens and Steiner (2004), $75 \mathrm{~mm}$ in Wilson and Holway (2010), $100 \mathrm{~mm}$ in Kuhn and Ambrose (1984) and $115 \mathrm{~mm}$ in Vinson et al. (2010). Lengths shorter than $150 \mathrm{~mm}$ have been linked to increases in male production (Gerber and Klostermeyer 1970; Gruber et al. 2011), but others have found no effect (Jay and Mohr 1987). Seidelmann (2006) attributes the bias to females provisioning less costly offspring (e.g. males) nearer the nest entrance where the risk of parasitism or nest predation is highest.

\subsection{Patterning and colour}

Patterning and colouration of the area around the nest box entrance can improve nest recognition when multiple suitable cavities are available (Krombein 1967; Fauria and Campan 1998; Fauria et al. 2004; Guédot et al. 2006; Lee-Mäder et al. 2010). The colour of the nest box entrance can improve bee productivity: Artz et al. (2014) found that Osmia lignaria provisioned 1.4 and 2.6 times more females in nest boxes that were light blue compared to orange- and yellow-coloured nest boxes. Excess patterning can confuse bees at the nest entrance too; for example, Guédot et al. (2007) found increasing disorientation at nests with high levels of contrasting colours and patterns. Disorientation can extend the duration of return foraging bouts, reducing the time dedicated to provisioning offspring and nest building, and so it is recommended that some patterning and colour be used on the exteriors of the nest box (Figure 1). 
Table II. List of plant species whose stems are collected to construct nest boxes to study cavity-nesting bees (and wasps)

\begin{tabular}{|c|c|c|c|c|}
\hline Species & Family & Common name & Example reference & Example taxa \\
\hline 'Bamboo' & - & 'Bamboo' & Rubene et al. (2015) & Multi \\
\hline 'Reed' & - & 'Reed' & Krewenka et al. (2011) & Multi \\
\hline $\begin{array}{l}\text { Phragmites australis } \\
\text { (Cav.) Trin. ex Steud. }\end{array}$ & Poaceae & Common Reed & Tscharntke et al. (1998) & Multi \\
\hline Saccharum spontaneum L. & Poaceae & Kans grass & Kessler et al. (2009) & Multi \\
\hline $\begin{array}{l}\text { Phyllostachys aurea } \\
\text { Riviere \& C.Riviere }\end{array}$ & Poaceae & $\begin{array}{l}\text { Golden } \\
\text { Bamboo }\end{array}$ & $\begin{array}{l}\text { Musicante and Salvo } \\
\text { (2010) }\end{array}$ & Trypoxylon* \\
\hline Arundo donax L. & Poaceae & Giant Cane & Tylianakis et al. (2006) & Multi \\
\hline $\begin{array}{l}\text { Fallopia japonica (Houtt.) } \\
\text { Ronse Decr. }\end{array}$ & Polygonaceae & $\begin{array}{l}\text { Japanese } \\
\text { knotweed }\end{array}$ & Klein et al. (2004) & Multi \\
\hline Ricinis communis & Euphorbiaceae & Castor & Abrol et al. (2015) & Megachilidae \\
\hline Xanthorrhoea minor R.Br. & Xanthorrhoeaceae & Grasstree & Bull and Schwarz (1996) & $\begin{array}{l}\text { Exoneura } \\
\text { bicolor }\end{array}$ \\
\hline Sambucus sp. & Adoxaceae & Elderberry & $\begin{array}{l}\text { Frohlich and Parker } \\
\text { (1983) }\end{array}$ & $\begin{array}{c}\text { Megachile } \\
\text { pugnata }\end{array}$ \\
\hline Rubus fruticosus L. sens.str. & Rosaceae & Blackberry & Danks (1971) & Multi \\
\hline Rubus strigosus Michx. & Rosaceae & Raspberry & $\begin{array}{l}\text { Vickruck and Richards } \\
\text { (2012) }\end{array}$ & Ceratina \\
\hline $\begin{array}{l}\text { Erythrina poeppigiana } \\
\text { (Walp.) O.F. Cook }\end{array}$ & Fabaceae & Dadap & Eickwort (1967) & $\begin{array}{l}\text { Chilicola } \\
\text { ashmeadi }\end{array}$ \\
\hline Dipteryx alata Vogel & Fabaceae & Baru Tree & $\begin{array}{l}\text { Loyola and Martins } \\
\text { (2008) }\end{array}$ & Multi \\
\hline Melia azedarach L. & Meliaceae & Chinaberry & Fye (1965a) & Multi \\
\hline Conium maculatum $\mathrm{L}$. & Apiaceae & $\begin{array}{l}\text { Poison } \\
\text { Hemlock }\end{array}$ & Rust et al. (1974) & $\begin{array}{l}\text { Osmia } \\
\text { nigrifrons }\end{array}$ \\
\hline $\begin{array}{l}\text { Ailanthus altissima (Mill.) } \\
\text { Swingle }\end{array}$ & Simaroubaceae & Tree of Heaven & Tormos et al. (2005) & Crabronidae* \\
\hline Rhus typhina $\mathrm{L}$. & Anacardiaceae & Sumac & $\begin{array}{l}\text { Koerber and Medler } \\
\text { (1958) }\end{array}$ & Multi \\
\hline
\end{tabular}

*Refers to studies that examine cavity-nesting wasps

However, more work is needed that examines the mechanisms behind nest recognition and associated improvements in productivity.

\subsection{Placement}

Local environmental factors impact the type and number of colonizers in nest boxes and so, placement requires careful attention to the surroundings (Gaston et al. 2005). Securing the nest box so that it does not move or fall over (e.g. a fence, pole, shed wall) is critical. Nest boxes not visited often also benefit from protective screens over the entrance to guard against attacks by birds or other wildlife
(Krunic et al. 2005). In an urban environment, Everaars et al. (2011) found more colonization of the target species Osmia bicornis (Linnaeus) in nest boxes attached to balconies and carport walls versus those attached to trees and shrubs. Another study found colonization of nest boxes on green roofs declined with increasing building height suggesting there are vertical limitations to where a nest box can be set up and colonization expected (MacIvor 2015). Nest boxes are also colonized less if facing prevailing winds (Martins et al. 2012). In general, placement is best facing south east and above the flower line so that the entrance is not blocked by vegetation. 


\section{MOTIVATIONS}

\subsection{Objective 1: to assess bee diversity and populations in natural settings}

Nest boxes can be constructed in a standardized way, and set up en masse to monitor regional diversity, mortality and natural history in both space and time (Tscharntke et al. 1998; Loyola and Martins 2006; Sheffield et al. 2008a; Gazola and Garófalo 2009; Forrest and Thomson 2011; Fabian et al. 2014). Nest boxes used to sample diversity of bees should include cavities with different internal diameters to accommodate species of different body sizes (O'Neill and O'Neill 2013). Sampling diversity within an environment or along a gradient should use many nest boxes to cover as wide a sampling area as possible, rather than single large nest boxes that are cumbersome. Access to larva may be required and so, designs that can easily be opened (wood panels) or are inexpensive so that they can be destroyed (cardboard/paper) are best.

Nest boxes allow researchers to assess numerous aspects of bee biology to interpret environment conditions; this includes pollen (Abel and Wilson 1998; MacIvor et al. 2014; Eckhardt et al. 2014) and nectar preferences (Burkle and Irwin 2009; Cane et al. 2011), as well as the spread of parasites (Paern et al. 2015), introduced species (e.g. Osmia tanneri Sandhouse: Torchio 1984) and invasive ones (e.g. Megachile sculpturalis Smith: Mangum and Sumner 2003). Saturating habitats with nest boxes can help monitor community change, range expansions or track target species. Colonized nest boxes can be moved between sites, altered in orientation or positioning, or bee cocoons 'seeded' in or removed (Fründ et al. 2013). The degree of manipulation and flexibility in studies using nest boxes allows for simple, low-cost and data-rich sampling to address questions in community ecology (Steffan-Dewenter 2002; Sheffield et al. 2008a; Westphal et al. 2008; Schüepp et al. 2011; Steckel et al. 2014). Most studies are carried out over 1 or 2 years but there are several that sample over $3+$ years. For example, a 17-year study of change in nest box colonizers with the introduction of the Africanized honey bee in
Mexico (Roubik and Villanueva-Gutierrez 2009), and another that monitored Osmia rufa off-and-on over 27 years in Ukraine (Ivanov 2006). Nest boxes can provide insight into multitrophic interactions to address bee conservation of species and the complexity of their needs (Tylianakis et al. 2006; Veddeler et al. 2010; Ebeling et al. 2012; MacIvor 2016).

Nest boxes that contain many cavities provide opportunities to increase the numbers of observations and replication in studies that examine bee behaviour (Trostle and Torchio 1994). Traditionally, studies that monitor activity at natural nesting cavities of bees are dependent on the search effort required of researchers to locate sufficient numbers of nests (e.g. Scott 1993). For example, Dobson and Peng (1997) collected nests of Chelostoma florisomne (Linnaeus) from dried stems of Phragmites comprising a thatched roof on an old farm in rural Sweden. Others document the nests of bees in the stems of different plants, such as Ceratina mikmaqi Rehan \& Sheffield and Ceratina calcarata Robertson in Dipsacus fullonum L., Rubus strigosus Michx. and Rhus typhina L. (Vickruck and Richards 2012) or Augochlora esox (Vachal) in the bromeliad, Aechmea lindenii (E. Morren) Baker (Zillikens et al. 2001). Natural history observations and reporting on the natural nesting materials used by bee species is critical to inform best practises for nest box design and implementation.

Nest boxes can also be used as the (nesting) point of reference to quantify the time spent foraging (Klostermeyer and Gerber 1969) or the minimum and maximum foraging distances travelled to a resource from the nest (Gathmann and Tscharntke 2002). Zurbuchen et al. (2010a) studied maximum flight distances using nest boxes and found they are considerably shorter and within dozens of meters of the nest for small bodied species. Manipulating the location or distance of nest boxes from marked resources can determine maximum foraging distances and help interpret landscape factors that support wild bee foraging requirements (Williams and Tepedino 2003). Marking and recapturing bees from nest boxes can be used as a method to examine floral availability or preference of different taxa 
(Steffan-Dewenter and Schiele 2004; Zurbuchen et al. 2010b; Yamamoto et al. 2014).

\subsection{Objective 2: to examine environmental factors that impact their populations}

In studies that use nest boxes to explore how environmental factors impact wild bees, it is recommended that standardized nest boxes that are easily replicated and durable for deployment over large geographic areas are used. Nest boxes should contain cavities with differently sized widths and that can be replaced so that sufficient and diverse nesting options are not limited to cavity-nesting bees throughout the entire sampling period. Durability in nesting material and the nest box exterior is key to withstand different and extreme environmental conditions.

Studying cavity-nesting bees with nest boxes has led to findings on how different environmental factors impact pollinators (Schüepp et al. 2011) and species diversity (Tscharntke et al. 1998; Tylianakis et al. 2007; Dorado et al. 2011; Fabian et al. 2013). Colonization and diversity in nest boxes along environmental gradients can be studied to understand the impacts of landscape change on bee communities (e.g. wetlands: Moroń et al. 2008; forest canopy cover: Sobek et al. 2009; heavy metal contamination: Moroń et al. 2012; mass-flowering agricultural crop: Diekötter et al. 2014; urban land use: Fortel et al. 2016) as well as the effects of fragmentation (Klein et al. 2006; Krewenka et al. 2011; Coudrain et al. 2014). Landscape changes have been linked to foraging and diet inefficiency in cavity-nesting bees (Levin and Haydak 1957; Raw 1974; Williams 2003) and increasing interactions with parasites (Münster-Swendsen and Calabuig 2000; Kruess and Tscharntke 2002). For example, Peterson and Roitberg (2006) found a decline in resources allocated to offspring in $M$. rotundata in nest boxes at further distances from a large floral patches.

Correlating local and landscape environmental conditions with nest box colonization and diversity can improve our understanding of how land use and planning decisions impact bees and pollination services (Steffan-Dewenter and Schiele 2008; Pereira-Peixoto et al. 2014). This might include proximity to and size of hedgerows, buffer strips, forest patches and other nearby habitat (Steffan-Dewenter 2002; Krewenka et al. 2011) that have landscape management implications and can be encouraged through policy, programs and incentives (Byrne and Fitzpatrick 2009).

\subsection{Objective 3: to augment bee abundance for pollination services}

A goal of many studies is to enhance the number of bees for pollination services of agricultural crops (Bohart 1972; Bosch and Kemp 2002; Jauker et al. 2012; Sedivy and Dorn 2014). Once a target bee species has been identified, its nesting preferences must be carefully researched to make nest boxes attractive habitat and enhance brood production (Parker and Frohlich 1983; Torchio et al. 1987; Wei et al. 2002; Wilkaniec et al. 2004; West and McCutcheon 2009). When populations have been established, nests can be moved around to target crops or regions of interest (Bosch and Kemp 2002). 'Seeding' bees into nest boxes can fast track the uptake by target species in order to build up large numbers (e.g. Williams and Kremen 2007). Several wild bees are successfully managed for agricultural applications using nest boxes including, for example, Osmia cornifrons (Radoszkowski) (Maeta and Kitamura 1974), O. bicornis (Gruber et al. 2011), O. lignaria (Bohart 1972; Philips and Klostermeyer 1978), O. cornuta (Bosch and Kemp 2002), and M. rotundata (Bohart 1972; Fairey et al. 1989; Pitts-Singer and Cane 2011).

Nest boxes are used to manage bees and augment their numbers for pollination of a multitude of crops including alfalfa (Wightman and Rogers 1978; Bosch and Kemp 2005), carrot (Tepedino and Frohlich 1984), onion (Giejdasz et al. 2005), rapeseed (Teper and Bilinski 2009), coffee (Laliberté and Tylianakis 2010), almond (Torchio 1981; Bosch 1994), blueberry (Stubbs et al. 1997; Sampson et al. 2004), cherry (Bosch et al. 2006), prune (Torchio 1976), acerola (Pina and Aguiar 2011; Magalhaes and Freitas 2013), apple (Wei et al. 2002; Sheffield et al. 2008b; Gruber et al. 2011) and passion fruit (Junquiera et al. 2012; Yamamoto et al. 2014). Fields containing other economically important plants have been surveyed 
too; for example, O’Neill et al. (2010) studied feral populations of $M$. rotundata at a wildflower seed farm. Multi-crop systems have been shown to harbour a greater diversity of cavity-nesting bees in nest boxes compared to monocrop systems (Banos-Picon et al. 2013).

There are many facets of nest box design to consider when the aim is to increase the abundance of target bee species (Kim 1992; Bosch and Kemp 2002). Nest boxes should be large and to improve offspring production should not be limited in the number of nesting cavities available (Levin 1957; Stephen 1961; Artz et al. 2014). Some bees are gregarious like O. bicornis (Seidelmann 2006) or M. rotundata (Pitts-Singer and Cane 2011) and abundantly colonize nest boxes where nesting holes are plentiful. However, aggregating large numbers of specific solitary bee species could facilitate the accumulation of natural enemies (Wcislo 1996; MacIvor and Packer 2015). Managing cavity-nesting bees for pollination management therefore requires large nest boxes that can be easily cleaned to reduce parasites (Cusumano et al. 2012) and pathogens (Goettel et al. 1997), as their accumulation can critically impact bee populations (Hobbs 1968; James 2005).

\subsection{Objective 4: to obtain bees for experimental study}

Nest boxes can be used as tools for obtaining bees for research that would be otherwise difficult to collect in the field. 'Farming' bees in nest boxes can lead to excess numbers that can be packaged and sold to others needing bees for experimental purposes. Nest boxes used for this objective should be designed to include numerous cavities all of a similar length and internal diameter to match the precise conditions preferred by the bee species of interest. Also, materials that can be easily opened, such as cardboard or paper tubes, so brood cells can be counted and species identified. This permits the control of bee emergence-to-adulthood, parasite levels and sex ratios which can be important criteria to identify prior to further research. Bees collected from nest boxes can be used for study in enclosures in laboratory settings, in flight cages, in green houses, or in the field (Frohlich 1983; Abel and Wilson 1998; Suguira and Maeta 1989; Goodell 2003). For example, by manipulating the diversity of bees seeded into nest boxes in flight cages, Fründ et al. (2013) showed additive impacts of bee diversity on pollination efficacy.

By obtaining bees from nest boxes, researchers can study the mechanisms relating to cavitynesting bee physiology and development, leading to better management and knowledge relevant for our understanding of all bees. Bees obtained from nest boxes have been used to understand bee incubation and overwintering conditions (e.g. Tepedino and Parker 1986; Kemp and Bosch 2001; Giejdasz and Wilkaniec 2002; Yocum et al. 2005; O'Neill et al. 2011; Fliszkiewicz et al. 2012; Fründ et al. 2013), sex ratio (e.g. Tepedino 1980; Longair 1981; Oku and Nishida 1999; Seidelmann et al. 2010), embryonic change (Torchio 1989), larval instar development (Whitfield et al. 1987), metabolism rates (Wightman and Rogers 1978), changes in egg size (Maeta and Suguira 1990), cocoon size (Tepedino and Parker 1986), larval orientation (Torchio 1980; Martins et al. 2012), diet (Sedivy et al. 2011; Haider et al. 2013), nest site fidelity (Steffan-Dewenter and Schiele 2004), supersedure (Delphia and O’Neill 2012), emergence timing and seasonality (Thiele 2005; Forrest and Thomson 2011), nest material preferences (Horne 1995; MacIvor 2016) and impacts of pesticides and other chemicals on bee health (Waller 1969; Torchio 1983; Alston et al. 2007; Konrad et al. 2008; Sandrock et al. 2014).

\section{CONCLUSIONS}

Nest boxes are inexpensive, can be set out in a wide variety of habitats and built using porous and preferably natural materials found locally and globally; for example, collected and dried invasive plants like $P$. australis and $P$. aurea. The popularity of nest boxes has greatly diversified the type and number of designs, users, and habitats where nest boxes are deployed. To study bee diversity along environmental gradients or in different habitats it is recommended that nest boxes are set out over as wide an area as possible and contain many cavities of different internal diameters. Nest boxes designed to augment numbers of 
bees for crop pollination or further experimentation should be made large and of a consistent material and dimension based on the preference of the target bee species.

Although not discussed in this review, numerous species of solitary wasps also use nest boxes (Danks 1971; Taki et al. 2008; Matsumoto and Makino 2011; Ebeling et al. 2012; Diekötter et al. 2014; Staab et al. 2014) and often abundantly (MacIvor and Packer 2015). Many of these cavitynesting wasps collect aphids, caterpillars and beetles, some of which are garden pests or are hyperabundant (Fye 1965b; Krombein 1967; Fricke 1991; Sears et al. 2001; Krewenka et al. 2011). More work is needed to identify what opportunities there are in using nest boxes to study and enhance cavity-nesting wasps, including the dual functional roles (e.g. pollination, pest-control) that nest boxes might contribute to natural and agricultural systems (Gathmann et al. 1994; Holzschuh et al. 2009; Barthélémy 2012; Fabian et al. 2014).

Nest boxes are increasingly sold at gardening centres and online (MacIvor and Packer 2015). Incorporating nest boxes into gardening practises that support pollinators could increase efforts of citizens to aid in data collection and enhance conditions for wild bees (Everaars et al. 2011). As concern and appreciation for non-honey bee species increases, the use of nest boxes as both a sampling tool and as habitat will increase and expand into new and innovated evidence-based applications.

\section{ACKNOWLEDGMENTS}

I thank Dr. Laurence Packer for his useful comments to the manuscript, as well as two anonymous reviewers. Thanks to Baharak Salehi and the PCYU lab for helpful discussion. Funding was provided by the Natural Sciences and Engineering Research Council of Canada (NSERC CGS D 408565) and support from the NSERC discover grant of Dr. Laurence Packer.

Gîtes de nidification artificiels pour abeilles solitaires: un siècle de design et de recherche

Abeilles nichant en cavité / gestion alternative des pollinisateurs / abeilles sauvages / biodiversité / agroécosystème / nid-piège / jardin
Hohlraum-Nistboxen für solitäre Bienen: Ein Jahrhundert über Design und Forschung

Hohlraum-nistende Bienen / Alternatives Bestäubungsmanagment / Wildbienen / Biodiversität / Agrarökosysteme / Nisthilfe / Bienenhotel / Bestäubergarten

\section{REFERENCES}

Abel, C. A., Wilson, R. L. (1998) The use of diverse plant species for increasing Osmia cornifrons (hymenoptera: Megachilidae) in field cages. J. Kansas Entomol. Soc. 71, 23-28.

Abrol, D. P., Shankar, U., Kapil, R. P. (2015) Utilization of waste materials for management of alfalfa pollinating megachilid bees. Entomol. Gen. 35, 177-185.

Alston, D. G., Tepedino, V. J., Bradley, B. A., Toler, T. R., Griswold, T. L., Messinger, S. M. (2007) Effects of the insecticide phosmet on solitary bee foraging and nesting in orchards of Capitol Reef National Park, Utah. Environ. Entomol. 36, 811-816.

Artz, D. R., Allan, M. J., Wardell, G. I., Pitts-Singer, T. L. (2014) Influence of nest box color and release sites on Osmia lignaria (hymenoptera: Megachilidae) reproductive success in a commercial almond orchard. J. Econ. Entomol. 107, 2045-2054.

Balfour-Browne, F. (1925) Concerning the habits of insects. Cambridge University Press, London.

Banos-Picon, L., Torres, F., Tormos, J., Gayubo, S. F., Asis, J. D. (2013) Comparison of two Mediterranean crop systems: polycrop favours trap-nesting solitary bees over monocrop. Basic Appl Ecol. 14, 255-262.

Barthélémy, C. (2012) Nest trapping, a simple method for gathering information on life histories of solitary bees and wasps. Bionomics of 21 species of solitary aculeate in Hong Kong. Hong Kong Entomol Bull. 4, 3-37.

Barthell, J. F., Frankie, G. W., Thorp, R. W. (1998) Invader effects in a community of cavity nesting megachilid bees (Hymenoptera: Megachilidae). Environ. Entomol. 27, 240-247.

Blochtein, B., Wittmann, D. (1988) Mating site specificity, reproduction and vector selection in Nemognatha nigrotarsata (Col., Meloidae), a nest parasite of leafcutter bees and other pollinators of crops in Rio Grande do Sul. J. Appl. Entomol. 105 (1-5), 414-419.

Bohart, G. E. (1955) Gradual nest supersedure within the genus Osmia . Proc. Entomol. Soc. Wash. 57, 203-204.

Bohart, G. E. (1972) Management of wild bees for the pollination of crops. Annu. Rev. Entomol. 17, 287312 .

Bosch, J. (1994) Osmia cornuta Latr.(Hym., Megachilidae) as a potential pollinator in almond orchards. J. Appl. Entomol. 117, 151-157.

Bosch, J., Kemp, W. P. (2002) Developing and establishing bee species as crop pollinators: the example of Osmia 
spp. (Hymenoptera: Megachilidae) and fruit trees. Bull. Entomol. Res. 92, 3-16.

Bosch, J., Kemp, W. P. (2005) Alfalfa leafcutting bee population dynamics, flower availability, and pollination rates in two Oregon alfalfa fields. J. Econ. Entomol. 98, 1077-1086.

Bosch, J., Kemp, W. P., Trostle, G. E. (2006) Bee population returns and cherry yields in an orchard pollinated with Osmia lignaria (hymenoptera: Megachilidae). J. Econ. Entomol. 99, 408-413.

Budriené, A., Budrys, E., Nevronyté, Ž. (2004) Solitary Hymenoptera aculeata inhabiting trap-nests in Lithuania: nesting cavity choice and niche overlap. Latvijas Entomol. 41, 19-31.

Bull, N.J., Schwarz, M.P. (1996) The habitat saturation hypothesis and sociality in an Allodapine bee: cooperative nesting is not "making the best of a bad situation”. Behav. Ecol. Sociobiol. 39, 267-274.

Burkle, L., Irwin R. (2009) Nectar sugar limits larval growth of solitary bees (Hymenoptera: Megachilidae). Environ. Entomol. 38, 1293-1300.

Byrne, A., Fitzpatrick, Ú. (2009) Bee conservation policy at the global, regional and national levels. Apidologie 40, 194-210.

Cane, J. H., Griswold, T., Parker, F. D. (2007) Substrates and materials used for nesting by north American Osmia bees (Hymenoptera: Apiformes: Megachilidae). Ann. Entomol. Soc. Am. 100, 350358.

Cane, J. H., Gardner, D. R., Harrison, P. A. (2011) Nectar and pollen sugars constituting larval provisions of the alfalfa leaf-cutting bee (Megachile rotundata) (Hymenoptera: Apiformes: Megachilidae). Apidologie 42, 401-408.

Coudrain, V., Schüepp, C., Herzog, F., Albrecht, M., Entling, M. H. (2014) Habitat amount modulates the effect of patch isolation on host-parasitoid interactions. Front Environ. Sci. 2, 1-27.

Coville, R. E., Griswold, C. (1984) Biology of Trypoxylon (Trypargilum) superbum (Hymenoptera: Sphecidae), a spider-hunting wasp with extended guarding of the brood by males. J. Kansas Entomol. Soc. 57, 365-376.

Cusumano, A., González, J. M., Colazza, S., Vinson, S. B. (2012) First report of Melittobia australica Girault in Europe and new record of $M$. acasta (Walker) for Italy. ZooKeys 181, 1-45.

Danks, H. V. (1971) Nest mortality factors in stem-nesting aculeate hymenoptera. J. Anim. Ecol. 40, 79-82.

Darling, D. C., Packer, L. (1988) Effectiveness of malaise traps in collecting Hymenoptera: the influence of trap design, mesh size, and location. Can. Entomol. 120, 787-796.

Deguines, N., Julliard, R., Flores, M., Fontaine, C (2016) Functional homogenization of flower visitor communities with urbanization. Ecol. Evol. 6, 1967-1976.

Delphia, C. M., O’Neill, K. M. (2012) Supersedure of Isodontia mexicana (Saussure)(hymenoptera: Sphecidae) nests by Megachile rotundata (F.)
(Hymenoptera: Megachilidae): do bees destroy wasp cocoons?. J. Kansas Entomol. Soc. 85, 380-383.

Dicks, L.V., Showler, D. A., Sutherland, W. J. (2010) Bee conservation: evidence for the effects of interventions (Vol. 1). London: Pelagic Publishing.

Diekötter, T., Peter, F., Jauker, B., Wolters, V., Jauker, F. (2014) Mass-flowering crops increase richness of cavity-nesting bees and wasps in modern agro-ecosystems. GCB Bioenergy 6, 219-226.

Dobson, H. E., Peng, Y. S. (1997) Digestion of pollen components by larvae of the flowerspecialist bee Chelostoma florisomne (Hymenoptera: Megachilidae). J. Insect Physiol. 43, 89100.

Dorado, J., Vásquez, D. P., Stevani, E. L., Chacoff, N. P. (2011). Rareness and specialization in plant-pollinator networks. Ecology 92, 19-25.

Ebeling, A., Klein, A. M., Weisser, W. W., Tscharntke, T. (2012) Multitrophic effects of experimental changes in plant diversity on cavity-nesting bees, wasps, and their parasitoids. Oecologia 169, 453-465.

Eckhardt, M., Haider, M., Dorn, S., Müller, A. (2014) Pollen mixing in pollen generalist solitary bees: a possible strategy to complement or mitigate unfavourable pollen properties? J. Animal Ecol. 83, 588-597.

Eickwort, G. C. (1967) Aspects of the biology of Chilicola ashmeadi in Costa Rica (Hymenoptera: Colletidae) J. Kansas Entomol. Soc. 40 : 42-73.

Everaars, J., Strohbach, M. W., Gruber, B., Dormann, C. F. (2011) Microsite conditions dominate habitat selection of the red mason bee (Osmia bicornis, Hymenoptera: Megachilidae) in an urban environment: a case study from Leipzig, Germany. Landscape Urban Plann 103, 15-23.

Fabian, Y., Sandau, N., Bruggisser, O. T., Aebi, A., Kehrli, P., Rohr, R. P., Naisbit, R. E., Bersier, L. F. (2013) The importance of landscape and spatial structure for hymenopteran-based food webs in an agro-ecosystem. J Anim Ecol. 82, 1203-1214.

Fabian, Y., Sandau, N., Bruggisser, O. T., Aebi, A., Kehrli, P., Rohr, R. P., Naisbit, R. E., Bersier, L. F. (2014) Plant diversity in a nutshell: testing for small-scale effects on trap nesting wild bees and wasps. Ecosphere 5, art18.

Fabre, J. H. (1918) The Mason-bees. Dodd, Mead, New York.

Fairey, D. T., Lieverse, J. A. C. (1986) Cell production by the alfalfa leafcutting bee (Megachile rotundata $\mathrm{F}$.) in new and used wood and polystyrene nesting materials. J. Appl. Entomol. 102, 148-153.

Fairey, D. T., Lefkovitch, L. P., Lieverse, J. A. C. (1989) The leafcutting bee, Megachile rotundata (F.): a potential pollinator for red clover. J. Appl. Entomol. 107, 52-57.

Fauria, K., Campan, R. (1998) Do solitary bees Osmia cornuta Latr. And Osmia lignaria Cresson use proximal visual cues to localize their nest?. J. Insect Behav. 11, 649-669. 
Fauria, K., Campan, R., Grimal, A. (2004) Visual marks learned by the solitary bee Megachile rotundata for localizing its nest. Anim. Behav. 67, 523-530.

Fliszkiewicz, M., Giejdasz, K., Wasielewski, O., Krishnan, N. (2012) Influence of winter temperature and simulated climate change on body mass and fat body depletion during diapause in adults of the solitary bee, Osmia rufa (hymenoptera: Megachilidae). Environ. Entomol. 41, 1621-1630.

Forrest, J. R. K., Thomson, J. D. (2011) An examination of synchrony between insect emergence and flowering in Rocky Mountain meadows. Ecol. Mono. 81, 469-491.

Fortel, L., Henry, M., Guilbaud, L., Mouret, H., Vaissière, B. E. (2016). Use of human-made nesting structures by wild bees in an urban environment. J. Insect Conserv. 20, 239-253.

Fricke, J. M. (1991) Trap-nest bore diameter preferences among sympatric Passaloecus spp. (Hymenoptera: Sphecidae). Great Lakes Entomol. 24, 123-125.

Frohlich, D. R. (1983) On the nesting biology of Osmia (Chenosmia) bruneri (Hymenoptera: Megachilidae). J. Kansas Entomol. Soc. 56, 123-130.

Frohlich, D. R., Parker, F. D. (1983) Nest building behavior and development of the sunflower leafcutter bee: Eumegachile (Sayapis) pugnata (Say) (Hymenoptera: Megachilidae). Psyche 90, 193-209.

Frost, S. W. (1943) An observation box for solitary bees and wasps. J. Econ. Entomol. 36, 803-804.

Fründ, J., Dormann, C. F., Holzschuh, A., Tscharntke, T. (2013) Bee diversity effects on pollination depend on functional complementarity and niche shifts. Ecology 94, 2042-2054.

Fussell, M., Corbet, S. A. (1992) Nesting places of some British bumble bees. J. Apic. Res. 31, 32-41.

Fye, R. E. (1965a) Biology of Apoidea taken in trap nests in northwestern Ontario (Hymenoptera). Can. Entomol. 97, 863-877.

Fye, R. E. (1965b) The biology of the Vespidae, Pompilidae, and Sphecidae (hymenoptera) from trap nests in northwestern Ontario. Can. Entomol. 97, 716744.

Gaston, K. J., Smith, R. M., Thompson, K., Warren, P. H. (2005) Urban domestic gardens (II): experimental tests of methods for increasing biodiversity. Biodiv. Conserv. 14, 395-413.

Gathmann, A., Tscharntke, T. (2002) Foraging ranges of solitary bees. J. Anim. Ecol. 71, 757-764.

Gathmann, A., Greiler, H. J., Tscharntke, T. (1994) Trapnesting bees and wasps colonizing set-aside fields: succession and body size, management by cutting and sowing. Oecologia 98, 8-14.

Gazola, A. L., Garófalo, C. A. (2003) Parasitic behavior of Leucospis cayennensis Westwood (Hymenoptera: Leucospidae) and rates of parasitism in populations of Centris (Heterocentris) analis (Fabricius) (Hymenoptera: Apidae: Centridini). J. Kansas Entomol. Soc. 76, 131-142.
Gazola, A. L., Garófalo, C. A. (2009) Trap-nesting bees (hymenoptera: Apoidea) in forest fragments of the state of Sao Paulo, Brazil. Genetics Res. 8, 607-622.

Gerber, H. S., Klostermeyer, E. C. (1970) Sex control by bees: a voluntary act of egg fertilization during oviposition. Science 167, 82-84.

Gezon, Z. J., Wyman, E. S., Ascher, J. S., Inouye, D. W., Irwin, R. E. (2015) The effect of repeated, lethal sampling on wild bee abundance and diversity. Meth. Ecol. Evol. DOI: 10.1111/2041-210X.12375.

Giejdasz, K., Wilkaniec, Z. (2002) Individual development of the red mason bee (Osmia rufa L., Megachilidae) under natural and laboratory conditions. J. Apic. Res. 46, 51-57.

Giejdasz, K., Wilkaniec, Z., Piech, K. (2005) Effects of seed onion pollination by red mason bee females Osmia rufa L. (Apoidea; Megachilidae) with different body weights. J. Apicult. Res. 49, 21-27.

Goettel, M. S., Duke, G. M., Goerzen, D. W. (1997) Pathogenicity of Ascosphaera larvis to larvae of the alfalfa leafcutting bee, Megachile rotundata. Can. Ent. 129, 1059-1065.

Goodell, K. (2003) Food availability affects Osmia pumila (Hymenoptera: Megachilidae) foraging, reproduction, and brood parasitism. Oecologia 134, 518-527.

Grixti, J. C., Packer, L. (2006) Changes in the bee fauna (Hymenoptera: Apoidea) of an old field site in southern Ontario, revisited after 34 years. Can. Ent. 138, 147-164.

Gruber, B., Eckel, K., Everaars, J., Dormann, C. F. (2011) On managing the red mason bee (Osmia bicornis) in apple orchards. Apidologie 42, 564-576.

Guédot, C., Pitts-Singer, T. L., Buckner, J. S., Bosch, J., Kemp, W. P. (2006) Olfactory cues and nest recognition in the solitary bee Osmia lignaria. Physiol. Entomol. 31,110-119.

Guédot, C., Bosch, J., Kemp, W. P. (2007) Effect of threedimension and color contrast on nest localization performance of two solitary bees (hymenoptera: Megachilidae). J. Kansas Entomol. Soc. 80, 90-104.

Haider, M., Dorn, S., Müller, A. (2013) Intra-and interpopulational variation in the ability of a solitary bee species to develop on non-host pollen: implications for host range expansion. Func. Ecol. 27, 255-263.

Hallett, P. E. (2001) A method for 'hiving' solitary bees and wasps. Am. Bee J. 1, 141.

Hartman, C. G., Hartman, P., Hartman, P., Rettenmeyer, C. (1944) Note on the habits of Osmia georgica Cresson as ascertained by the glass-tube method. Psyche 51, $162-165$.

Hicks, C. H. (1937) Methods of rearing wild bees, wasps, and their parasites. In: Culture methods for invertebrate animals (Eds: Galtsoff P. S., F. E. Lutz, P. S. Welsh, J. G. Needham. Comstock Publishing Company Inc. Chicago, Ill.

Hobbs, G. A. (1968) Controlling insect enemies of the alfalfa leaf-cutter bee, Megachile rotundata. Can. Ent. 100, 781-784. 
Holzschuh, A., Steffan-Dewenter, I., Tscharntke, T. (2009) Grass strip corridors in agricultural landscapes enhance nest-site colonization by solitary wasps. Ecol. Appl. 19, 123-132.

Horne, M. (1995) Leaf area and toughness: effects on nesting material preferences of Megachile rotundata (hymenoptera: Megachilidae). Ann. Entomol. Soc. Am 88, 868-875.

Ivanov, S. P. (2006) The nesting of Osmia rufa (L.) (Hymenoptera, Megachilidae) in the Crimea: structure and composition of nests. Entomol. Rev. 86, 524-533.

James, R. R. (2005) Impact of disinfecting nesting boards on chalkbrood control in the alfalfa leafcutting bee. J. Econ. Entomol. 98, 1094-1100.

Jauker, F., Peter, F., Wolters, V. Diekötter, T. (2012). Early reproductive benefits of mass-flowering crops to the solitary bee Osmia rufa outbalance post-flowering disadvantages. Basic Appl. Ecol. 13, 268-276.

Jay S. C., Mohr, N. (1987) The effect of nest replacement on the production of females of the alfalfa leaf-cutter bee Megachile rotundata $(\mathrm{F})$. J. Apic. Res. 26, 69-72.

Jennings, D. T., Parker, F. D. (1987) Habitats and spider prey of Dipogon sayi (Hymenoptera: Pompilidae) in Washington County, Maine. Great Lakes Entomol. 20, 135-140.

Junquiera, C. N., Hogendoorn, K., Augusto, S. C. (2012) The use of trap-nests to manage carpenter bees (Hymenoptera: Apidae: Xylocopini), pollinators of passion fruit (Passifloraceae: Passiflora edulis F. flavicarpa). Ann. Entomol. Soc. Am. 105, 884-889.

Kearns, C. A., Inouye, D. W. (1993) Techniques for pollination biologists. Boulder, Colorado: University Press of Colorado.

Kemp, W.P., Bosch, J. (2001) Postcocooning temperatures and diapause in the alfalfa pollinator Megachile rotundata (hymenoptera: Megachilidae). Ann. Entomol. Soc. Am. 94, 244-250.

Kessler, M., Abrahamczyk, S., Bos, M., Buchori, D., Putra, D. D., et al. (2009) Alpha and beta diversity of plants and animals along a tropical land-use gradient. Ecol. Appl. 19, 2142-2156.

Kim, J. Y. (1992) Nest dimensions of two leaf-cutter bees (hymenoptera: Megachilidae). Ann. Entomol. Soc. Am. 85, 85-90.

Klein, A. M., Steffan-Dewenter, I., Tscharntke, T. (2004). Foraging trip duration and density of megachilid bees, eumenid wasps and pompilid wasps in tropical agroforestry systems. Journal of Animal Ecology, 73, 517525.

Klein, A., Steffan-Dewenter, I., Tscharntke, T. (2006) Rain forest promotes trophic interactions and diversity of trap-nesting Hymenoptera in adjacent agroforestry. J. Anim. Ecol. 75, 315-323.

Klostermeyer, E. C., Gerber, H. S. (1969) Nesting behavior of Megachile rotundata (Hymenoptera: Megachilidae) monitored with an event recorder. Ann. Entomol. Soc. Am. 62 , 1321-1325.
Koerber, T. W., Medler, J. T. (1958) A trap-nest survey of solitary bees and wasps in Wisconsin, with biological notes. Trans. Wisconsin Acad. Sci. Arts Lett. 47: 5363.

Konrad, R., Ferry, N., Gatehouse, A. M., Babendrier, D. (2008) Potential effects of oilseed rape expressing oryzacystatin-1 (OC-1) and of purified insecticidal proteins on larvae of the solitary bee Osmia bicornis . PLoS ONE 3 , e2664.

Krewenka, K. M., Holzschuh, A., Tscharntke, T., Dormann, C. F. (2011) Landscape elements as potential barriers and corridors for bees, wasps and parasitoids. Biol. Conserv. 144, 1816-1825.

Krombein, K. V. (1967) Trap-nesting wasps and bees: life histories, nests, and associates. Smithsonian Institutional Press, Washington D.C.

Kruess, A., Tscharntke, T. (2002) Grazing intensity and the diversity of grasshoppers, butterflies, and trap-nesting bees and wasps. Conserv. Biodiv. 16, 1570-1580.

Krunic, M., Stanisavljevic, L., Pinzauti, M., Felicioli, A. (2005) The accompanying fauna of Osmia cornuta and Osmia rufa and effective measures of protection. Bull. Insect. 58, 141-152.

Kuhn, E. D., Ambrose, J. T. (1984) Pollination of 'delicious' apple by megachilid bees of the genus Osmia (Hymenoptera: Megachilidae). J. Kansas Entomol. Soc. 57, 169-180.

Laliberté, E., Tylianakis, J. M. (2010) Deforestation homogenizes tropical parasitoid-host networks. Ecology 91, 1740-1747.

Lee-Mäder, E., Spivak, M., Evans, E. (2010) Managing Alternative pollinators: a handbook for beekeepers, growers, and conservationists. Sustainable Agriculture Research and Education.

Levin, M. D. (1957) Artificial nesting burrows for Osmia lignaria Say. J. Econ. Entomol. 50, 506-507.

Levin, M. D., Haydak, M. H. (1957) Comparative value of different pollens in the nutrition of Osmia lignaria Say. Bee World 38, 221-226.

Longair, R. W. (1981) Sex ratio variations in xylophilous aculeate Hymenoptera. Evolution 35, 597-600.

Loyola, R. D., Martins, R. P. (2006) Trap-nest occupation by solitary wasps and bees (Hymenoptera: Aculeata) in a forest urban remnant. Neotrop. Entomol. 35, 41-48.

Loyola, R.D., Martins, R. P. (2008) Habitat structure components are effective predictors of trap-nesting Hymenoptera diversity. Basic Appl Ecol. 9, 735-742.

MacIvor, J. S. (2015) Building height matters: nesting activity of bees and wasps on vegetated roofs. Israel J. Ecol. Evol. DOI:10.1080/ 15659801.2015.1052635

MacIvor, J. S. (2016) DNA barcoding to identify leaf preference of leafcutting bees. Royal Soc. Open Sci. 3, 150623 .

MacIvor, J. S., Packer, L. (2015) 'Bee hotels' as tools in native pollinator conservation: a premature verdict?. PLoS-ONE 10, e0122126. 
MacIvor, J. S., Cabral, J. M., Packer, L. (2014) Pollen specialization by solitary bees in an urban landscape. Urb. Ecosyst. 17, 139-147.

Maeta, Y., Kitamura, T. (1964). Studies on the apple pollination of Osmia I. Idea and present conditions in utilizing Osmia as pollinators of apples in Japan. Kontyû, 32, 45-52.

Maeta, Y., Kitamura, T. (1974) How to manage the Mameko bee (Osmia cornifrons Radoszkowski) for pollination of fruit crops. Tokyo: Ask Co Ltd. 16pp.

Maeta, Y., Suguira, N. (1990) Decision-making in a mason bee, Osmia cornifrons (Radoszkowski) (Hymenoptera, Megachilidae): does the mother bee fertilize her eggs depending on their sizes?. Japan J. Entomol. 58, 197-203.

Magalhaes, C. B., Freitas, B. M. (2013) Introducing nests of the oil-collecting bee Centris analis (Hymenoptera: Apidae: Centridini) for pollination of acerola (Malpighia emarginata) increases yield. Apidologie 44, 234-239.

Malaise, R. (1937) A new insect-trap. Entomol. Tidsk. 58 : 148-160.

Mangum, W. A., Sumner, S. (2003) A survey of the north American range of Megachile (Callomegachile) sculpturalis, an adventive species in North America. J. Kansas Entomol. Soc. 76, 658-662.

Martins, C. F., Ferriera, R. P., Carneiro, L. T. (2012) Influence of the orientation of nest entrance, shading, and substrate on sampling trap-nesting bees and wasps. Neotrop. Entomol. 41, 105-111.

Matsumoto, K., Makino, S. I. (2011) Monitoring of tubenesting bees and wasps with bamboo tube nest traps of different types in two types of forests in temperate Japan. Entomol. Sci. 14, 154-161.

Medler, J. T. (1958) A note on Megachile inermis Prov. In trap-nests in Wisconsin (Hymenoptera: Magachilidae). Can. Entomol. 90 : 325-327.

Medler, J. T. (1965) A note on Ancistrocerus tigris in trapnests in Wisconsin (Hymenoptera: Vespidae). J. Kansas Entomol. Soc. 38, 314-316.

Medler, J. T., Fye, R. E. (1956) Biology of Ancistrocerus antilope (Panzer) (Hymenoptera, Vespidae) in trap-nests in Wisconsin. Ann. Entomol. Soc. Am. 49, 97-102.

Moroń, D., Szentgyörgyi, H., Wantuch, M., Celary, W., Westphal, C., Settele, J., Woyciechowski, M. (2008) Diversity of wild bees in wet meadows: implications for conservation. Wetlands 28, 975-983.

Moroń, D., Grzes, I. M., Skorka, P., Szentgyörgyi, H., Laskowski, R., Potts, S. G., Woyciechowski, M. (2012) Abundance and diversity of wild bees along gradients of heavy metal pollution. J. Appl. Ecol. 49, 118-125.

Münster-Swenden, M., Calabuig, I. (2000) Interaction between the solitary bee Chelostoma florisomne and its nest parasite Sapyga clavicornis - empty cells reduce the impact of parasites. Ecol. Entomol. 25, 63-70.

Musicante, M. L., Salvo, A. (2010) Nesting biology of four species of Trypoxylon (Trypargilum) (hymenoptera:
Crabronidae) in Chaco Serrano woodland, Central Argentina. Rev. Biol. Trop. 58, 1177-1188.

O’Neill, K. M., O’Neill, J. F. (2010) Cavity-nesting wasps and bees of Central New York state: the Montezuma wetlands complex. Northeast. Nat. 17, 455-472.

O’Neill K. M., O’Neill, J. F. (2013) Cavity-nesting wasps and bees (Hymenoptera) of Central New York state: the Roy H. Park preserve and Dorothy Mcilroy bird sanctuary. J. Entomol. Soc. Wash. 115 : DOI: 10.4289/ 0013-8797.115.2.158

O’Neill, K. M., Pearce, A. M., O’Neill, R. P., Miller, R. S. (2010) Offspring size and sex ratio variation in a feral population of alfalfa leafcutting bees (Hymenoptera: Megachilidae). Ann. Entomol. Soc. Am. 103, 775784.

O’Neill, K. M., O’Neill, R. P., Kemp, W. P., Delphia, C. M. (2011) Effect of temperature on post-wintering development and total lipid content of alfalfa leafcutting bees. Environ. Entomol. 40, 917-930.

Oku, S., Nishida, T. (1999) Factors affecting female-biased sex ratio in a trap-nesting wasp, Trypoxylon malaisei . Res. Pop. Ecol. 41, 169-175.

Paern, M., Soon, V., Vallisoo, T., Hovi, K., Luig, J. (2015) Host specificity of the tribe Chrysidini (Hymenoptera: Chrysididae) in Estonia ascertained with trap-nesting. Eur. J. Entomol, 112, 91-99.

Paini, D. R. (2004) Nesting biology of an Australian resin bee (Megachile sp.; Hymenoptera: Megachilidae): a study using trap nests. Aus. J. Entomol. 43, 10-15.

Parker, F. D., Frohlich, D. R. (1983). Hybrid sunflower pollination by a manageable composite specialist: the sunflower leafcutter bee (Hymenoptera: Megachilidae). Environmental Entomology, 12 , 576-581

Peck, O., Bolton, J. L. (1946) Alfalfa seed production in northern Saskatchewan as affected by bees, with a report on the means of increasing the populations of native bees. Sci. Agric. 26, 338-418.

Pereira-Peixoto, M. H., Pufal, G., Martins, C. F., Klein, A. M. (2014) Spillover of trap-nesting bees and wasps in an urban-rural interface. J. Insect Conserv. 18, 815-826.

Peterson, J. H., Roitberg, B. D. (2006) Impacts of flight distance on sex ratio and resource allocation to offspring in the leafcutter bee, Megachile rotundata. Behav. Ecol. Sociobiol. 59, 589-596.

Phillips, J. K., Klostermeyer, E. C. (1978) Nesting behavior of Osmia lignaria propinqua Cresson (Hymenoptera: Megachilidae). J. Kansas Entomol. Soc. 5, 91-108.

Pina, W. D., Aguiar, C. M. L. (2011) Trap-nesting bees (Hymenoptera: Apidae) in orchards of acerola (Malpighia emarginata) in a semiarid region of Brazil. Sociobiology 58, 379-392.

Pitts-Singer, T. L., Cane, J. H. (2011) The alfalfa leafcutting bee, Megachile rotundata: the world's most intensively managed solitary bee. Annu. Rev. Entomol. 56, 221-237.

Radmacher, S., Strohm, E. (2010) Factors affecting offspring body size in the solitary bee Osmia bicornis (Hymenoptera, Megachilidae). Apidologie 4, 169-177. 
Radmacher, S., Strohm, E. (2011) Effects of constant and fluctuating temperatures on the development of the solitary bee Osmia bicornis (Hymenoptera: Megachilidae). Apidologie 42, 711-720.

Rau, P. (1937) The life-history of Osmia lignaria and O. cordata, with notes on $O$. conjuncta. Ann. Entomol. Soc. Am. 30, 324-343.

Raw, A. (1972) The biology of the solitary bee Osmia rufa (L.)(Megachilidae). Trans. R. Entomol. Soc. Lon. 124, 213-229.

Raw, A. (1974) Pollen preferences of three Osmia species (hymenoptera). Oikos 25, 54-60.

Richards, K. W. (1978) Comparisons of nesting materials used for the alfalfa leafcutter bee, Megachile pacifica (hymenoptera: Megachilidae). Can. Ent. 110, 841-846.

Richards, M. H., Rutgers-Kelly, A., Gibbs, J., Vickruck, J. L., Rehan, S. M., Sheffield, C. S. (2011) Bee diversity in naturalizing patches of Carolinian grasslands in southern Ontario, Canada. Can. Ent. 143, 279-299.

Rothschild, M. (1979) Factors influencing size and sex ratios in Megachile rotundata (hymenoptera: Megachilidae). J. Kansas Entomol. Soc. 52, 392-401.

Roubik, D. W., Villaneuva-Gutierrez, R. (2009) Invasive Africanized honey bee impact on native solitary bees: a pollen resource and trap nest analysis. Biol. J. Linn. Soc. 98, 152-160.

Rubene, D., Schroeder, M., Ranius, T. (2015) Diversity patterns of wild bees and wasps in managed boreal forests: effects of spatial structure, local habitat and surrounding landscape. Biol. Conserv. 184, 201-208.

Rust, R.W., Thorp, R.W., Torchio, P.F. (1974) The ecology of Osmia nigrifrons with a comparison to other Acanthosmioides. J. Nat. Hist. 8, 29-47.

Sampson, B. J., Stringer, S. J., Cane, J. H., Spiers, J. M. (2004) Screenhouse evaluations of a mason bee Osmia ribifloris (Hymenoptera: Megachilidae) as a pollinator for blueberries in the southeastern United States. Small Fruits Rev. 3, 381-392.

Sandrock, C., Tanadini, L.G., Pettis, J. S., Biesmeijer, J. C., Potts, S. G., Neumann, P. (2014) Sublethal neonicotinoid insecticide exposure reduces solitary bee reproductive success. Agric. Forest Entomol. 16, 119-128.

Schüepp, C., Herrman, J. D., Herzog, F., Schmidt-Entling, M. H. (2011) Differential effects of habitat isolation and landscape composition on wasps, bees, and their enemies. Oecologia 165, 713-721.

Scott, V. (1993) Use of communal nest entrances by Osmia simillima (Hymenoptera: Megachilidae). Great Lakes Entomol. 26, 79-80.

Sears, A. L., Smiley, J. T., Hilker, M., Müller, F., Rank, N. E. (2001) Nesting behavior and prey use in two geographically separated populations of the specialist wasp Symmorphus cristatus (Vespidae: Eumeninae). Am. Midland Nat. 145, 233-246.

Sedivy, C., Dorn, S. (2014) Towards a sustainable management of bees of the subgenus Osmia (Megachilidae; Osmia ) as fruit tree pollinators. Apidologie 45, 88-105.
Sedivy, C., Müller, A., Dorn, S. (2011) Closely related pollen generalist bees differ in their ability to develop on the same pollen diet: evidence for physiological adaptations to digest pollen. Funct. Ecol. 25, 718-725.

Seidelmann, K. (2006) Open-cell parasitism shapes maternal investment patterns in the red Mason bee Osmia rufa. Behav. Ecol. 17, 839-848.

Seidelmann, K., Ulbrich, K., Meilenz, N. (2010) Conditional sex allocation in the red Mason bee, Osmia rufa . Behav. Ecol. Sociobiol. 64, 337-347.

Sekita, N., Yamada, M. (1993) Use of Osmia cornifrons for pollination of apples in Aomori prefecture, Japan. Jap. Agric. Res. Quart. 26, 264-264.

Sheffield, C. S., Kevan, P. G., Westby, S. M., Smith, R. F. (2008a) Diversity of cavity-nesting bees (Hymenoptera: Apoidea) within apple orchards and wild habitats in the Annapolis Valley, Nova Scotia, Canada. Can. Ent. 140, 235-249.

Sheffield, C. S., Westby, S. M., Smith, R. F., Kevan, P. G. (2008b) Potential of bigleaf lupine for building and sustaining Osmia lignaria populations for pollination of apple. Can. Ent. 140, 589-599.

Sheffield, C. S., Wilkes, M. A., Cutler, C. G., Hermanutz, L. (2014) An artificial nesting substrate for Osmia species that nest under stones, with focus on Osmia inermis (Hymenoptera: Megachilidae). Insect Conserv. Div. 8, 189-192.

Silva, M. D., Ramahlo, M., Monteiro, D. (2014) Communities of social bees (Apidae: Meliponini) in trap-nests: the spatial dynamics of reproduction in an area of Atlantic Forest. Neotrop. Entomol. 43, 307-313.

Sobek, S., Tscharntke, T., Schreber, C., Schiele, S., SteffanDewenter, I. (2009) Canopy vs. understory: does tree diversity affect bee and wasp communities and their natural enemies across forest strata?. Forest Ecol. Manage. 258, 609-615.

Staab, M., Ohl, M., Zhu, C. D., Klein, A. M. (2014) A unique nest-protection strategy in a new species of spider wasp. PloS one, 9, e101592.

Steckel, J., Westphal, C., Peters, M. K., Bellach, M., Rothenwoehrer, C., Erasmi, S., Schreber, C., Tscharntke, T., Steffan-Dewenter, I. (2014) Landscape composition and configuration differently affect trapnesting bees, wasps and their antagonists. Biol. Conserv. 172, 56-64.

Steffan-Dewenter, I. (2002) Landscape context affects trapnesting bees, wasps, and their natural enemies. Ecol. Entomol. 27, 631-637.

Steffan-Dewenter, I., Schiele, S. (2004) Nest-site fidelity, body weight and population size of the red mason bee, Osmia rufa (hymenoptera: Megachilidae), evaluated by mark-recapture experiments. Entomol. Gen. 27, $123-131$.

Steffan-Dewenter, I., Schiele, S. (2008) Do resources or natural enemies drive bee population dynamics in fragmented habitats. Ecology 89, 1375-1387.

Stephen, W. P. (1961) Artificial nesting sites for the propagation of the leaf-cutter bee, Megachile 
(Eutricharaea) rotundata, for alfalfa pollination. J. Econ. Entomol. 54, 989-993.

Stephen, W. P., Every, R. W. (1970) Nesting media for the propagation of leaf cutter bees. Corvallis, Oregon Extension Service, Oregon State University.

Stephen, W. P., Osgood, C. E. (1965) Influence of tunnel size and nesting medium on sex ratios in a leaf-cutter bee, Megachile rotundata. J. Econ. Entomol. 58, 965-968.

Stubbs, C. S., Drummond, F. A., Osgood, E. A. (1994) Osmia ribifloris biedermannii and Megachile rotundata (Hymenoptera: Megachilidae) introduced into the lowbush blueberry agroecosystem in Maine. J. Kansas Entomol. Soc. 67, 173-185.

Stubbs, C. S., Drummond, F. A., Allard, S. L. (1997). Bee conservation and increasing Osmia spp. in Maine lowbush blueberry fields. Northeast. Nat. 4, 133-144.

Suguira, N., Maeta, Y. (1989) Parental investment and offspring sex ratio in a solitary mason bee, Osmia cornifrons (Radoszkowski) (hymenoptera, Megachilidae). J. Entomol. Soc. Japan 57, 861-875.

Taki, H., Viana, B. F., Kevan, P. G., Silva, F. O., Buck, M. (2008) Does forest loss affect the communities of trapnesting wasps (Hymenoptera: Aculeata) in forests? Landscape vs. local habitat conditions. J. Insect Conserv. 12, 15-21.

Tepedino, V. J. (1980) Sex ratio of Hylaeus bisinuatus Forster (Hymenoptera: Colletidae). J. Kansas Entomol. Soc. 53, 805-810.

Tepedino, V. J., Frohlich, D. R. (1984) Fratricide in Megachile rotundata, a non-social megachilid bee: impartial treatment of sibs and non-sibs. Behav. Ecol. Sociobiol. 15, 19-23.

Tepedino, V. J., Parker, F. D. (1986) Effect of rearing temperature on mortality, second-generation emergence, and size of adult in Megachile rotundata (Hymenoptera: Megachilidae). J. Econ. Entomol. 79, 974-977.

Teper, D., Bilinski M. (2009) Red mason bee (Osmia rufa L.) as a pollinator of rape plantations. J. Apic. Sci. 53, 115-120.

Thiele, R. (2005) Phenology and nest site preferences of wood-nesting bees in a Neotropical lowland rain forest. Stud. Neotrop. Fauna Environ. 40, 39-48.

Torchio, P. F. (1976) Use of Osmia lignaria Say (Hymenoptera: Apoidea, Megachilidae) as a pollinator in an apple and prune orchard. J. Kansas Entomol. Soc. 49, 475-482.

Torchio, P. F. (1980) Factors affecting cocoon orientation in Osmia lignaria propinqua Cresson (Hymenoptera: Megachilidae). J. Kansas Entomol. Soc. 53, 386-400.

Torchio, P. F. (1981) Field experiments with Osmia lignaria propinqua Cresson as a pollinator in almond orchards: II, 1976 studies (Hymenoptera: Megachilidae). J. Kansas Entomol. Soc. 54, 824-836.

Torchio, P. F. (1983) The effects of field applications of naled and trichlorfon on the alfalfa leafcutting bee, Megachile rotundata (Fabricius). J. Kansas Entomol. Soc. 56, 62-68.
Torchio, P. F. (1984) Discovery of Osmia tanneri Sandhouse (Hymenoptera: Megachilidae) nesting in drilled wood trap nests. J. Kansas Entomol. Soc. 57, 350-352.

Torchio, P. F. (1989) In-nest biologies and development of immature stages of three Osmia species (hymenoptera: Megachilidae). Ann. Entomol. Soc. Am. 82, 599-615.

Torchio, P. F., Asensio, E., Thorp, R. W. (1987) Introduction of the European bee, Osmia cornuta, into California almond orchards (Hymenoptera: Megachilidae). Environ. Entomol. 16, 664-667.

Tormos, J., Asís, J. D., Gayubo, S. F., Calvo, J., Martín, M. A. (2005). Ecology of crabronid wasps found in trap nests from Spain (Hymenoptera: Spheciformes). Florida Entomologist, 88 , 278-284.

Trostle, G., Torchio, P. F. (1994) Comparative nesting behavior and immature development of Megachile rotundata (Fabricius) and Megachile apicalis Spinola (Hymenoptera: Megachilidae). J. Kansas Entomol. Soc. 67, 53-72.

Tscharntke, T., Gathmann, A., Steffan-Dewenter, I. (1998) Bioindication using trap-nesting bees and wasps and their natural enemies: community structure and interactions. J. Appl. Ecol. 35, 708-719.

Tylianakis, J.M., Klein, A.M., Tscharntke, T. (2005) Spatiotemporal variation in the diversity of Hymenoptera across a tropical habitat gradient. Ecology 86, 32963302.

Tylianakis, J.M., Tscharntke, T., Klein, A.M. (2006) Diversity, ecosystem function, and stability of parasitoidhost interactions across a tropical habitat gradient. Ecology 87, 3047-3057.

Tylianakis, J. M., Tscharntke, T., Lewis, O. T. (2007) Habitat modification alters the structure of tropical hostparasitoid food webs. Nature 445, 202-205.

Veddeler, D., Tylianakis, J., Tscharntke, T., Klein, A. M. (2010) Natural enemy diversity reduces temporal variability in wasp but not bee parasitism. Oecologia 162 , $755-762$.

Vickruck, J. L., Richards, M. H. (2012) Niche partitioning based on nest site selection in the small carpenter bees Ceratina mikmaqi and C. calcarata. Anim. Behav. 83, 1083-1089.

Vinson, S. B., Frankie, G., Cônsoli, R. (2010) Description, comparison and identification of nests of cavitynesting Centris bees (Hymenoptera: Apidae: Centridini) in Guanacaste Province, Costa Rica. J. Kansas Entomol. Soc. 83, 25-46.

Waller, G. D. (1969) Susceptibility of an alfalfa leaf cutting bee to residues of insecticides on foliage. J. Econ. Entomol. 62, 189-192.

Wcislo, W. T. (1996) Parasitism rates in relation to nest site in bees and wasps (Hymenoptera: Apoidea). J. Insect Behav. 9, 643-656.

Wei, S. G., Wang, R., Smirle, M. J., Xu, H. L. (2002) Release of Osmia excavata and Osmia jacoti (Hymenoptera: Megachilidae) for apple pollination. Can. Ent. 134, 369-380. 
West, T. P., McCutcheon, T. W. (2009) Evaluating Osmia cornifrons as pollinators of highbush blueberry. Int. J. Fruit Sci. 9, 115-125.

Westphal, C., Bommarco, R., Carre, G., Lamborn, E., Morison, N., et al. (2008) Measuring bee diversity in different European habitats and biogeographical regions. Ecol. Monogr. 78, DOI: 10.1890/07-1292.

Whitfield, G. H., Richards, K. W., Kveder, T. M. (1987) Number of instars of larvae of the alfalfa leafcutter bee, Megachile rotundata (F.) (Hymenoptera: Megachilidae). Can. Ent. 119, 859-865.

Wightman, J. A., Rogers, V. M. (1978) Growth, energy and nitrogen budgets and efficiencies of the growing larvae of Megachile pacifica (panzer) (Hymenoptera: Megachilidae). Oecologia 36, 245-257.

Wilkaniec, Z., Giejdasz, K., Proszynski, G. (2004) Effect of pollination of onion seeds under isolation by red mason bee (Osmia rufa L.) (Apoidea: Megachilidae) on the setting and quality of obtained seeds. J. Apic. Sci. 49, 35-41.

Williams, N. M. (2003) Use of novel pollen species by specialist and generalist solitary bees (Hymenoptera: Megachilidae). Oecologia 134, 228-237.

Williams, N. M., Kremen, C. (2007) Resource distributions among habitats determine solitary bee offspring production in a mosaic landscape. Ecol. Appl. 17, 910 921.

Williams, N. M., Tepedino, V. J. (2003) Consistent mixing of near and distant resources in foraging bouts by the solitary mason bee Osmia lignaria. Behav. Ecol. 14, 141-149.
Wilson, E. E., Holway, D. A. (2010) Multiple mechanisms underlie displacement of solitary Hawaiian Hymenoptera by an invasive social wasp. Ecology 91, 3294-3302.

Wilson, R. L., Abel, C. A., McClurg, S. G. (1999) Osmia spp. reared in artificial nesting sites in a backyard environment J. Iowa Acad. Sci. 106, 4-7.

Yamamoto, M., Junquiera, C. N., Barbosa, A. A. A., Augusto, S. C., Oliviera, P. E. (2014) Estimating crop pollinator population using mark-recapture method. Apidologie 45, 205-214.

Yocum, G. D., Kemp, W. P., Bosch, J., Knoblett, J. N. (2005) Temporal variation in overwintering gene expression and respiration in the solitary bee Megachile rotundata. J. Insect Physiol. 51, 621-629.

Zillikens, A., Steiner, J. (2004) Nest architecture, life cycle and cleptoparasite of the Neotropical leaf-cutting bee Megachile (Chrysosarus) pseudanthidioides Moure (Hymenoptera: Megachilidae). J. Kansas Entomol. Soc. 77, 193-202.

Zillikens, A., Steiner, J., Mohalkó, Z. (2001) Nests of Augochlora (a.) esox in bromeliads, a previously unknown site for sweat bees (Hymenoptera: Halictidae). Stud. Neotrop. Fauna Environ. 36, 137-142.

Zurbuchen, A., Landert, L., Klaiber, J., Müller, A., Hein, S., Dorn, S. (2010a) Maximum foraging ranges in solitary bees: only few individuals have the capability to cover long foraging distances. Biol. Conserv. 143, 669-676.

Zurbuchen, A., Bachofen, C., Müller, A., Hein, S., Dorn, S. (2010b) Are landscape structures insurmountable barriers for foraging bees? A mark-recapture study with two solitary pollen specialist species. Apidologie 41, 497-508. 